\title{
PENGGUNAAN KONSENTRAT LIMBAH SERBUK KAYU ULIN SEBAGAI COATING KAYU
}

\section{THE USE OF WASTE CONCENTRATES "ULIN" SAWDUST AS WOOD COATING.}

\author{
Titiek Pujilestari \\ Balai Riset dan Standardisasi Industri Samarinda \\ Jln Harmonika Nomor 3 Samarinda, Email : brisi_sam@yahoo.com \\ Naskah diterima 3 Pebruari 2011, disetujui 10 Mei 2011
}

\begin{abstract}
ABSTRAK
Pembuatan konsentrat zat ekstraktif limbah serbuk kayu ulin menggunakan pelarut air panas menghasilkan rendemen sebesar 8,40 \%. Aplikasi penggunaan konsentrat yang diperoleh dengan air panas sebagai coating pada kayu karet menggunakan metoda perendaman dan pelaburan pada konsentrasi $1 \%, 2 \%$ dan $3 \%$. Serangan jamur dinyatakan dengan pengukuran luas koloni dalam $\mathrm{mm}^{2}$, metoda perendaman memberikan hasil serangan jamur lebih kecil dibanding dengan metoda pelaburan. Rata-rata retensi pada konsentrasi $2 \%$ mempunyai nilai paling tinggi dibanding pada konsentrasi $1 \%$ dan $3 \%$, baik pada pelaburan maupun pada perendaman. Penyusutan kayu pada semua perlakuan tertinggi pada arah tangensial 2,19$5,94 \%$, semakin menurun pada arah radial 1,34 - 4,85\% dan paling rendah arah longitudinal $0,10-0,56 \%$
\end{abstract}

Kata kunci : coating, konsentrat, kayu ulin, serbuk.

\section{ABSTRACT}

Preparation of extractive waste substances concentrate "ulin" sawdust produce hot water using a solvent yield of $8.40 \%$. The application concentrates obtained by use of hot water as a coating on rubber wood using immersion methods and resurfacing at a concentration of $1 \%, 2 \%$ and $3 \%$. Fungal colonies revealed by extensive measurements in $\mathrm{mm} 2$, immersion method gives results of fungal attack was smaller than with the method of resurfacing. Average retention at a concentration of $2 \%$ has the highest value compared to the concentration of $1 \%$ and $3 \%$, both on the resurfacing and the immersion. Shrinkage of wood in all treatments the highest in the tangential direction from 2.19 to $5.94 \%$, the decrease in the radial direction from 1.34 to $4.85 \%$ and the lowest longitudinal direction from 0.10 to $0.56 \%$

Keywords : concentrated, coating, sawdust, ulin wood.

\section{PENDAHULUAN}

ayu ulin (Eusideroxylon zwageri) adalah jenis kayu yang cukup dikenal di
Kalimantan, digolongkan dalam family Lauraceae dan mempunyai sifat ketahanan kayu awet satu dan kelas 
kuat satu yang banyak digunakan sebagai bahan konstruksi terutama pada daerah yang terendam air (jembatan, dermaga, tiang pancang) juga sebagai papan sirap dan bagian bangunan lain. (Anonim, 2004).

Penyebaran kayu ulin terdapat diberbagai propinsi diantaranya Jambi, Sumatera Selatan, Bangka Belitung, Kalimantan Timur, Kalimantan Tengah, Kalimantan Selatan dan Kalimantan Barat, dengan berbagai nama daerah selain ulin yaitu Belian, Kayu Besi, Onglen. Kayu Ulin umumnya ditemukan dihutan primer dataran rendah dan dapat tumbuh pada ketinggian $400 \mathrm{~m}$ diatas permukaan laut.

Kayu Ulin adalah jenis kayu yang banyak digunakan oleh masyarakat Kalimantan sebagai bahan bangunan termasuk lantai, dinding, tiang, kusen dan daun pintu. Dengan perkembangannya ulin tidak saja memenuhi kebutuhan konsumsi lokal tetapi juga telah diolah dan diperdagangkan keluar daerah karena permintaan kayu yang semakin meningkat sehingga mengakibatkan potensi ulin akan menipis dan cenderung dibatasi dan dilindungi.

Walaupun potensi kayu ulin mulai berkurang, namun masih ada industri olahan kayu ulin yang memanfaatkannya untuk kebutuhan lokal. Industri pengolahan kayu ulin tersebut disamping menghasilkan produk olahan kayu ulin, dihasilkan juga limbah serbuk kayu ulin yang dapat dimanfaatkan untuk produk olahan lainnya.

Kayu ulin mengandung zat warna merah coklat dan zat ekstraktif yang berguna sebagai bahan pengawet pada kayu dan memberikan warna khas kayu ulin. Apabila kayu ulin direndam dalam air, maka akan meninggalkan warna merah kecoklatan pada air bekas rendaman. Substansi yang menentukan arah zat warna alam merupakan senyawa organik yang sering disebut coloring matter. Jenis coloring matter yang terdapat dalam sumber zat warna alam biasanya termasuk golongan tannin, baik bentuk hydrolysable tannins maupun condensed tannins (Rosamah, 1990).

Flavonoid, stibelena, tannin ,antosianin dan eusiderin merupakan golongan zat warna ekstraktif yang ada di kayu . Kemudian Hillis (1987) dalam Evalina Herawati (2005) mengatakan bahwa flavonoid merupakan senyawa yang menyebabkan kayu teras berwarna merah, kuning dan coklat atau biru. Polyfenol dan tannin pada kayu daun lebar memiliki kontribusi yang besar pada warna kayu .

Mengingat kayu hutan mulai berkurang maka perlu suatu usaha untuk memanfaatkan kayu jenis lain sebagai substitusi kayu hutan alam dengan perlakuan coating serbuk kayu ulin, sehingga diharapkan akan diperoleh jenis kayu yang mempunyai keawetan dan warna seperti kayu ulin. Harapan kedepan nantinya kayu substitusi ini menjadi andalan dalam memenuhi kebutuhan kayu baik lokal maupun luar negeri.

\section{METODOLOGI}

\section{Bahan dan Peralatan}

Bahan yang digunakan pada penelitian adalah serbuk kayu ulin yang diekstrak zat warna dan untuk aplikasi coating digunakan kayu karet. Serbuk kayu ulin diperoleh dari salah satu industri pengolahan kayu dan kayu karet diperoleh langsung dari perkebunan rakyat pada tahun 2010 dikota Samarinda, Propinsi Kalimantan Timur. Bahan penolong untuk mempertegas sifat coating antara lain manutex, polivinil acetat (PVAc), topcoat yang diperoleh dari toko bahan kimia di Yogyakarta, air dan beberapa bahan penolong untuk pengujian kultur jamur.

Peralatan yang digunakan meliputi evaporator, pengering vacum, oven, neraca, desikator , petridish, pengaduk kayu, kuas, kain saring, gelas piala, kompor serta beberapa peralatan untuk keperluan pengujian. 


\section{Metode}

Metode penelitian meliputi beberapa tahapan yaitu pembuatan konsentrat dari serbuk kayu ulin dengan sistim rendaman air panas, aplikasi penggunaan konsentrat untuk coating kayu karet dan pengujian terhadap hasil coating. Pengamatan meliputi dua faktor yaitu pertama proses coating dengan perendaman dan pelaburan. Dan kedua konsentrasi konsentrat serbuk kayu ulin $1 \%, 2 \%$ dan $3 \%$.

\section{Ekstraksi Serbuk Kayu Ulin dengan Air Panas}

Pastikan serbuk kayu ulin tidak tercampur dari ranting ataupun potongan kayu yang berukuran lebih besar dan tidak tercampur dengan serbuk kayu lainnya. Kemudian serbuk kayu ditimbang untuk mengetahui berat awal sebagai penentuan perhitungan rendemen konsentrat.

Masukan serbuk kayu dalam panci dan tambahkan air dengan perbandingan $1: 2$ atau sampai serbuk kayu terendam seluruhnya, kemudian direbus/dipanaskan selama 3 (tiga) jam. Setelah dingin dilakukan penyaringan menggunakan kain saring sehingga diperoleh filtrat dan ampas. Filtrat kemudian ditampung dalam suatu tempat/jerigen, yang merupakan campuran dari beberapa kali perebusan.

Campuran filtrat dari beberapa perebusan kemudian dipekatkan dengan cara penguapan dengan memanaskan selama 2 (dua) jam, kemudian didinginkan dan disaring kembali sehingga diperoleh filtrat pekat. Filtrat pekat dikeringkan dengan oven pada suhu $105^{\circ} \mathrm{C}$ sampai kering sehingga diperoleh konsentrat kering.

\section{Aplikasi Penggunaan Konsentrat untuk Coating Kayu Karet}

Batang kayu karet dibuat dolog dengan panjang satu meter, kemudian diambil secara acak kayu bagian terasnya untuk dibuat contoh uji. Dolog kayu dibelah hingga diperoleh contoh uji dengan ukuran tebal $2 \mathrm{~cm}$, lebar 3 $\mathrm{cm}$ dan panjang $10 \mathrm{~cm}$. Contoh uji setelah kering udara pada kedua ujungnya ditutup dengan cat kemudian ditimbang untuk mengetahui kadar air awal sebelum perlakuan.

Persiapan awal aplikasi coating dengan sistim rendaman yaitu pembuatan konsentrat serbuk kayu ulin dengan konsentrasi $0 \%$ (blanko), $1 \%$, $2 \%$ dan $3 \%$. Contoh uji direndam dalam larutan konsentrat masing masing sesuai perlakuan selama $2 \times 24$ jam. Angkat contoh uji dan dikering anginkan.

Pada sistim pelaburan dibuat larutan konsentrat dengan konsentrasi $1 \%, 2 \%$ dan $3 \%$. Tambahkan bahan pengental alami berupa karaginan rumput laut dengan nama dagang Manutex sesuai dengan kekentalan yang diinginkan. Larutan ini kemudian dilakukan pelaburan terhadap contoh uji dan diamkan kering angin, kemudian pelaburan diulang lagi sampai rata, biarkan sampai kering.

Pengujian dilakukan terhadap rendemen konsentrat yang diperoleh dengan ekstraksi air panas. Parameter uji hasil coating kayu karet dengan cara perendaman dan pelaburan meliputi penghambatan pertumbuhan jamur pelapuk kayu, retensi, penetrasi, kadar air, kerapatan, penyusutan kayu sesuai arah serat kayu radial, tangensial dan longitudinal serta daya serap air.

\section{HASIL DAN PEMBAHASAN}

Ekstraksi serbuk kayu ulin dengan air panas melalui beberapa tahapan kegiatan meliputi pemanasan, penyaringan, penguapan, pengeringan dan penghalusan untuk mendapatkan konsentrat yang lembut dan berukuran seragam dengan hasil rendemen rata - 
rata sebesar $8,4 \%$. Konsentrat hasil ekstraksi mengandung bahan aktif sebagai pengawet pada kayu, karena adanya komponen aktif seperti alkaloid, triterpenoid, steroid, saponin, flafonoid yang merupakan penghambat serangan jamur dan bahan pewarna khas kayu ulin (Fauziati, 2008)

Pengujian ketahanan coating terhadap serangan jamur pewarna menggunakan jamur Aspergilus niger dengan masa inkubasi selama 2 (dua) minggu pada contoh uji dengan konsentrasi $1 \%, 2 \%$ dan $3 \%$ seperti Gambar 1.

Hasil pengukuran ketahanan coating dari konsentrat serbuk kayu ulin terhadap serangan jamur diamati pada masing - masing sisi contoh uji (enam sisi), coating dengan cara perendaman luas koloni berkisar antara $39-58$ $\mathrm{mm}^{2}$ dan dengan cara pelaburan serangan luas koloni $79-287 \mathrm{~mm}^{2}$.

Masih terdapatnya serangan jamur pada perlakuan coating dengan cara perendaman dan pelaburan diduga saat pembuatan konsentrat pada tahap penyaringan, dalam residu masih tertahan senyawa aktif triterpenoid dan flavonoid sehingga dalam filtrat senyawa aktifnya berkurang. Dari hasil penelitian diperoleh bahwa ketahanan coating terhadap jamur menunjukkan cara perendaman memberikan hasil serangan luas koloni jamur lebih kecil dibanding cara pelaburan seperti Gambar 1. Hal ini karena dengan cara perendaman adanya komponen senyawa aktif banyak terserap pada pori - pori kayu karet. Hal ini sesuai pendapat Fauziati (2008) bahwa dalam ekstrak kayu ulin terdapat adanya kandungan alkaloid, triterpenoid dan flavonoid. Alkaloid memiliki sifat anti jamur dan diyakini berpotensi dalam mencegah adanya jamur perusak kayu. Tripenoid dan flavonoid merupakan dua golongan senyawa yang berperan dalam aktifitas penghambatan pertumbuhan jamur.

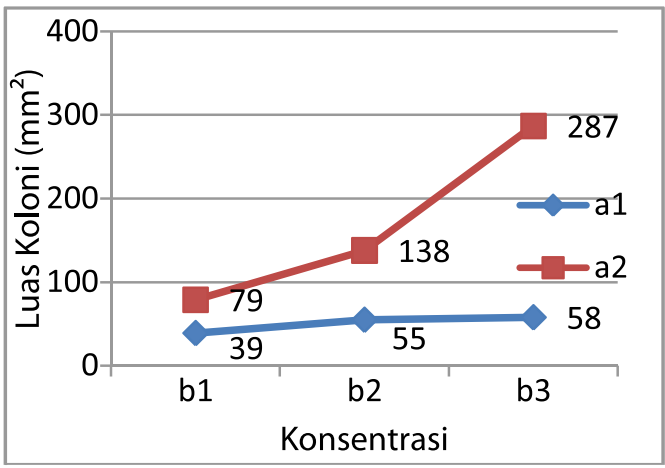

Keterangan:

$a_{1}=$ perendaman, $a_{2}=$ pelaburan, $b_{1}=$ konsentrasi $1 \%, b_{2}=$ konsentrasi $2 \%$ dan $b_{3}$ $=$ konsentrasi $3 \%$

Gambar 1 : Rerata Pengukuran Serangan Jamur pada Kayu Karet.

Hasil pengujian retensi, penetrasi, kadar air dan kerapatan pada coating kayu karet dengan cara perendaman dan pelaburan pada konsentrasi $1 \%, 2$ $\%$ dan $3 \%$ seperti pada Gambar 2 .

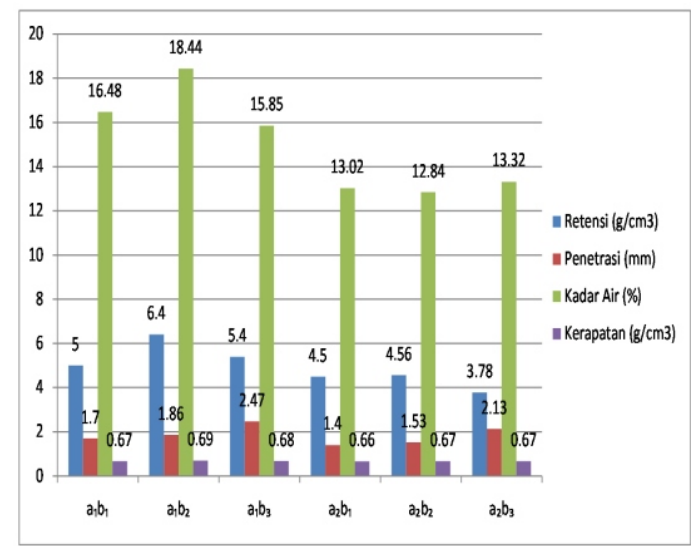

Keterangan:

$a_{1}=$ perendaman, $a_{2}=$ pelaburan, $b_{1}=$ konsentrasi $1 \%, b_{2}=$ konsentrasi $2 \%$ dan $b_{3}$ $=$ konsentrasi $3 \%$

Gambar 2 : Nilai Retensi Penetrasi, Kadar Air dan Kerapatan

Nilai retensi rata-rata $3,78-6,40$ $\mathrm{g} / \mathrm{cm}^{3}$. Penggunaan zat ekstraktif sebagai coating dengan cara perendaman memberikan hasil ratarata lebih besar dari pada cara pelaburan. Dengan cara perendaman partikel-partikel dalam bahan coating mudah masuk dalam pori-pori kayu, sedang pada cara pelaburan bahan coating bersifat agak kental sehingga sulit menembus pori-pori dan hanya 
menutup pada permukaan kayu. Penambahan konsentrasi zat ekstraktif tidak menaikkan nilai retensi, tetapi pada konsentrasi $2 \%$ baik pada cara perendaman maupun pelaburan memberikan nilai retensi paling besar. Menurut Hunt dan Garrat (1986) dalam Masyamah (2007) mengatakan bahwa keragaman penyerapan bahan pengawet sebagian besar ditentukan oleh perbedaan viskositas cairan bahan pengawet.

Hasil penetrasi rata-rata pada proses perendaman 1,70 - 2,47 mm dan pada proses pelaburan adalah 1,40 - 2,13 mm. Penetrasi adalah masuknya zat ekstraktif kedalam contoh uji menurut arah panjang kayu (longitudinal). Jenis bahan coating dan proses coating berpengaruh terhadap penetrasi, hal ini sesuai dengan hasil penetrasi dengan menggunakan perendaman memberikan penetrasi yang lebih besar dari pada pelaburan, karena proses perendaman menyerap maksimal bahan coating dan mudah menembus masuk dalam arah serat kayu. Pada proses pelaburan disamping ditambahkan bahan pengental pada formulasinya juga proses pelaburan sebagian besar hanya menutupi pada permukaan kayu.

Kadar air kayu coating proses perendaman berkisar 15,85 - 18,44\% dan pada pelaburan $12,84-13,32 \%$. Kadar air pada perlakuan perendaman rata-rata lebih tinggi dari pada perlakuan pelaburan. Adanya perlakuan perendaman selama 2x24 jam maka larutan coating akan masuk dalam serat kayu sampai kondisi jenuh serat, dengan demikian saat contoh uji diangkat dan dikering anginkan masih terdapat air yang terikat dalam serat kayu. Pada perlakuan pelaburan, bahan coating dioleskan pada permukaan kayu sehingga larutan tidak masuk menembus bagian dalam serat kayu. Rendahnya kadar air pada proses pelaburan disebabkan karena sifat dari coating yang dalam formulasinya ditambahkan bahan pengental sehingga contoh uji lebih stabil karena permukaan pori-pori yang tertutup dengan konsentrat coating.

Kerapatan kayu coating pada perlakuan perendaman maupun pelaburan menunjukkan hasil yang tidak berbeda, rata-rata berkisar 0,66 $0,69 \mathrm{~g} / \mathrm{cm}^{3}$. Kerapatan yang dimaksud adalah berat contoh uji setelah perlakuan coating dalam satuan volume tertentu dan dinyatakan dalam $\mathrm{g} / \mathrm{cm}^{3}$. Semakin tinggi kerapatan berarti kualitas kayu semakin kuat, karena adanya pori-pori yang semakin padat.

Hasil rata-rata penyusutan arah radial, tangensial dan longitudinal dari perlakuan coating dengan proses perendaman dan pelaburan disajikan pada Gambar 3.

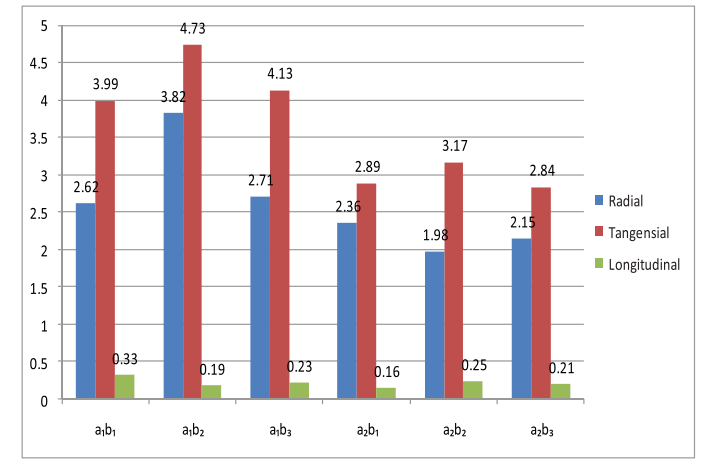

Keterangan:

$a_{1}=$ perendaman, $a_{2}=$ pelaburan, $b_{1}=$ konsentrasi $1 \%, b_{2}=$ konsentrasi $2 \%$ dan $b_{3}$ $=$ konsentrasi $3 \%$

Gambar 3 : Penyusutan Kayu Karet Hasil Coating

Penyusutan kayu hasil coating ekstrak serbuk kayu ulin dengan proses perendaman dan pelaburan pada konsentrasi $1 \%$, $2 \%$ dan $3 \%$ rata-rata menunjukkan penyusutan arah tangential paling tinggi yaitu $2,84-4,73$ $\%$ kemudian pada arah radial 1,98 $3,82 \%$ dan paling rendah pada arah longitudinal $0,16-0,33 \%$. Penyusutan pada proses perendaman lebih tinggi dibanding proses pelaburan. Adanya penyusutan yang tinggi disebabkan karena pori-pori kayu yang tidak tertutup sempurna oleh bahan coating. Pada pelaburan pori-pori kayu tertutup 
bahan coating yang ditambahkan bahan pengental. Penyusutan dapat berpengaruh terhadap kestabilan dimensi kayu, semakin tinggi penyusutan maka kayu akan mudah retak.

Pengujian daya tahan terhadap kelunturan dilakukan dengan cara merendam contoh uji masing-masing perlakuan kedalam air dingin selama 6x24 jam. Pengamatan warna daya tahan coating ekstrak ulin terhadap kelunturan dilakukan secara visual menunjukkan bahwa air hasil rendaman tetap jernih dan warna pada kayu tidak berubah, dengan demikian berarti coating ekstrak kayu ulin pada kayu karet memiliki daya tahan terhadap kelunturan.

\section{KESIMPULAN}

Ekstraksi serbuk kayu ulin dengan air panas memberikan hasil konsentrat sebagai bahan coating sebesar $8,4 \%$. Perlakuan coating pada kayu karet dengan cara perendaman terdapat serangan luas koloni jamur lebih kecil dibanding cara pelaburan. Penggunaan variasi konsentrasi larutan pada perlakuan tidak menunjukkan hasil yang signifikan. Perlakuan perendaman memberikan hasil lebih baik dari pada proses pelaburan dengan nilai retensi 5,0 - 6,40 $\mathrm{gram} / \mathrm{cm}^{2}$ dan kerapatan 0,67 - 0,69 $\mathrm{gram} / \mathrm{cm}^{2}$. Nilai retensi pada perlakuan perendaman dan pelaburan paling tinggi terdapat pada konsentrasi $2 \%$. Hasil coating serbuk kayu ulin pada kayu karet terhadap kelunturan warna menunjukkan tidak terjadi perubahan baik pada proses perendaman maupun pelaburan.

\section{DAFTAR PUSTAKA}

Anonim, 2004. Status Litbang Ulin (Eusideroxilon zwageri Teijsm dan Binn), Balai Penelitian dan Pengembangan Kehutanan Kalimantan Timur, Samarinda.

Dumanauw, J.F. 2001. Mengenal Kayu. PT Gramedia, Jakarta.

Rosamah, E 1990. Laporan Penelitian Peranan Zat Ekstraktif terhadap Keawetan Kayu Jati, Institut Pertanian, Bogor.

Herawati, E 2005. Warna Alami Kayu. Jurusan Kehutanan Universitas Sumatera Utara, Medan

Fauziati, 2008. Pengembangan Pemanfaatan Resin sebagai Coating Produk Mebel dan Kerajinan di Kaltim, Balai Riset dan Standardisasi Industri, Samarinda.

Masyamah, 2007. Pengawetan Rotan Diameter Kecil untuk Bahan Baku Industri. Kumpulan Hasil Penelitian Bidang Kayu, Rotan dan Bambu. Balai Riset dan Standardisasi Industri, Banjarbaru. 